\begin{tabular}{c}
\hline Review of \\
ECONOMICS \\
and \\
INSTITUTIONS
\end{tabular}

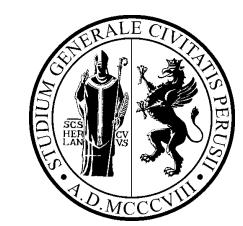

www.rei.unipg.it

\title{
Are Global Imbalances Sustainable? Post Crisis Scenarios
}

\author{
Luiz de Mello \\ OECD
}

Pier Carlo Padoan

OECD

\begin{abstract}
This paper assesses the sustainability of global imbalances by testing for the presence of unit roots in the current account positions (measured in relation to GDP) of the United States, China, Japan, Germany and the oil-exporting countries using a methodology that allows for structural breaks in levels and trends. We find that the external positions of these major countries/regions are stationary around structural breaks, which define episodes of current account reversals. On the basis of an event analysis of past reversals, it appears that structural breaks are associated with shifts in the fiscal stance, exchange rate parities and potential output growth, a finding that underscores the scope for macroeconomic and structural policies to ensure the sustainability of external positions while avoiding potentially disruptive reversals. These findings have implications for long-term capital flows after the crisis.
\end{abstract}

JEL classification: F30, O40, J08

Keywords: global imbalances, current account sustainability, capital flows

The authors thank, without implicating, participants at the Second International Conference on "The Long-Term Investments in the Age of Globalisation", Academia dei Lincei, Rome, 17 June 2010, and colleagues at the Department of Economics of the OECD for helpful comments and discussions. Special thanks go to Linda Rousova for research analysis. The opinions expressed in this paper are the authors' own and do not necessarily reflect those of the OECD and the Organisation's member countries.

\section{Introduction}

Global imbalances, measured as the sum in absolute terms of the current account balances of major countries/regions, nearly halved in the aftermath of the global crisis after reaching a post war high of over $5 \%$ of world GDP in 2008. The United States deficit accounted for about two-

Corresponding author. Address: OECD Economics Department, 2, rue André Pascal, 75775 Paris Cedex 16, France. (Phone: +33-1 45248752, Email: luiz.demello@oecd.org).

\section{Recommended Citation}

de Mello, L., \& Padoan, P.C. (2010). Are Global Imbalances Sustainable? Post Crisis Scenarios. Review of Economics and Institutions, 2(1), Article 3. doi: 10.5202/rei.v2i1.3. Retrieved from http://www.rei.unipg.it/rei/article/view/23 
thirds of the combined balance of deficit countries prior to the crisis and was matched almost entirely by the current account surpluses of Japan, China, Germany and the oil exporting countries. Global imbalances are now widening again on the back of the ongoing recovery of the world economy, although China's current account surplus continues to decline in relation to GDP Widening global imbalances are not necessarily undesirable, to the extent that they reflect increased financial integration and a more efficient allocation of global savings across countries. ${ }^{1}$ But a growing gap between the external positions of deficit and surplus countries has raised concern about the sustainability of such imbalances and the risks that disruptive movements in exchange rates and capital flows could pose for global growth. ${ }^{2}$ Past experience shows that current account reversals following rising global imbalances can be sizeable, as was the case in the mid-1980s, before imbalances began to rise gradually through 2008.

In this paper, we shed further light on the sustainability of global imbalances by first testing for the presence of unit roots in the current account positions (measured in relation to GDP) of the United States, China, Japan, Germany and the oil-exporting countries using a methodology that allows for structural breaks in intercepts and trends. We find that the external positions of these major countries/regions are stationary around structural breaks, which define episodes of current account reversals. In other words, global imbalances build up while remaining sustainable for a period of time, until a structural break occurs. On the basis of an event analysis of past reversals, it appears that structural breaks are associated with shifts in the fiscal stance, exchange rate parities and potential output growth, a finding that underscores the scope for macroeconomic and structural policies to ensure the sustainability of external positions while avoiding potentially disruptive reversals.

The findings of the unit root tests and event analysis, which are essentially backward-looking, are complemented by a series of simulations carried out using the OECD Global Model, reported in OECD (2010a) and summarised in this paper. The simulations refer to alternative policy scenarios that could be considered to deal with the current crisis,

\footnotetext{
${ }^{1}$ It has been argued that increased capital mobility across countries and deeper financial markets in individual countries may be consistent with widening current account imbalances (Gourinchas and Rey, 2005; Mendoza et al., 2007).

${ }^{2}$ Of course, tensions over global imbalances are not new. In the early 1970s, mounting current account mismatches led to the demise of the Bretton Woods system of fixed exchange rates. In the 1980 s, imbalances widened again and prompted international efforts to coordinate exchange rate movements under the G5/G7 Plaza (1985) and Louvre (1987) arrangements. External current account positions began to diverge yet again in the early 1990s and the ensuing reversals in capital flows contributed to the emerging market crises of the second half of the decade.
} 
which is itself clearly a major structural break. The simulations suggest that fiscal consolidation and the associated exchange rate adjustments would contribute to a reduction in global imbalances over the longer term, but the largest gains would come from a mix of structural reform that could reduce consumption in deficit countries and savings in surplus countries. A number of structural reforms, discussed briefly in the paper, are meritorious in their own right and would have the side-effect of addressing global imbalances.

The paper is organised as follows. Section 2 reviews trends in global imbalances and current account developments in the major countries/regions. Section 3 reports the main findings of an event analysis of the behaviour of fiscal policy, exchange rates and potential output growth around current account reversals on the basis of a procedure to identify structural breaks in the current account balances of the world's major countries/regions. Section 4 reports the results of simulations of different policy scenarios on global imbalances and summarises the structural reform actions taken in OECD countries that would also have a bearing on their external positions. Section 5 draws some implications for long-term capital flows in the post-crisis scenarios. Section 6 concludes.

\section{Trends in Global Imbalances}

\subsection{Longer-Term Trends}

Global imbalances, measured as the sum in absolute terms of the current account positions of the world's major countries/regions, have exhibited sharp swings over the last 40 years but rarely reached the precrisis level of over 5\% of world GDP in 2008 (Figure 1). ${ }^{3}$ Imbalances rose sharply in the first half of the 1980s, following the second oil shock, and peaked at the middle of the decade, between the Plaza and Louvre agreements on exchange rate management. Imbalances began to rise again gradually in the second half of the 1990s, an upward trend that came to an end with the global crisis in 2008. The United States has accounted for the lion's share of the world's current account deficits since the early 1980s. But the mix of surplus countries has changed, with the emergence of Germany, China and the oil-exporting countries as the main surplus countries/regions.

\footnotetext{
${ }^{3}$ External imbalances are also sizeable within the euro area, where large current account surpluses (in relation to GDP) in Germany and Netherlands are matched by large deficits in Greece, Ireland, Portugal and Spain. See OECD (2009a and 2010a) for more information.
} 
Figure 1 - Global imbalances, 1970-2010 - Current account balances, ${ }^{*}$ in \% of world GDP

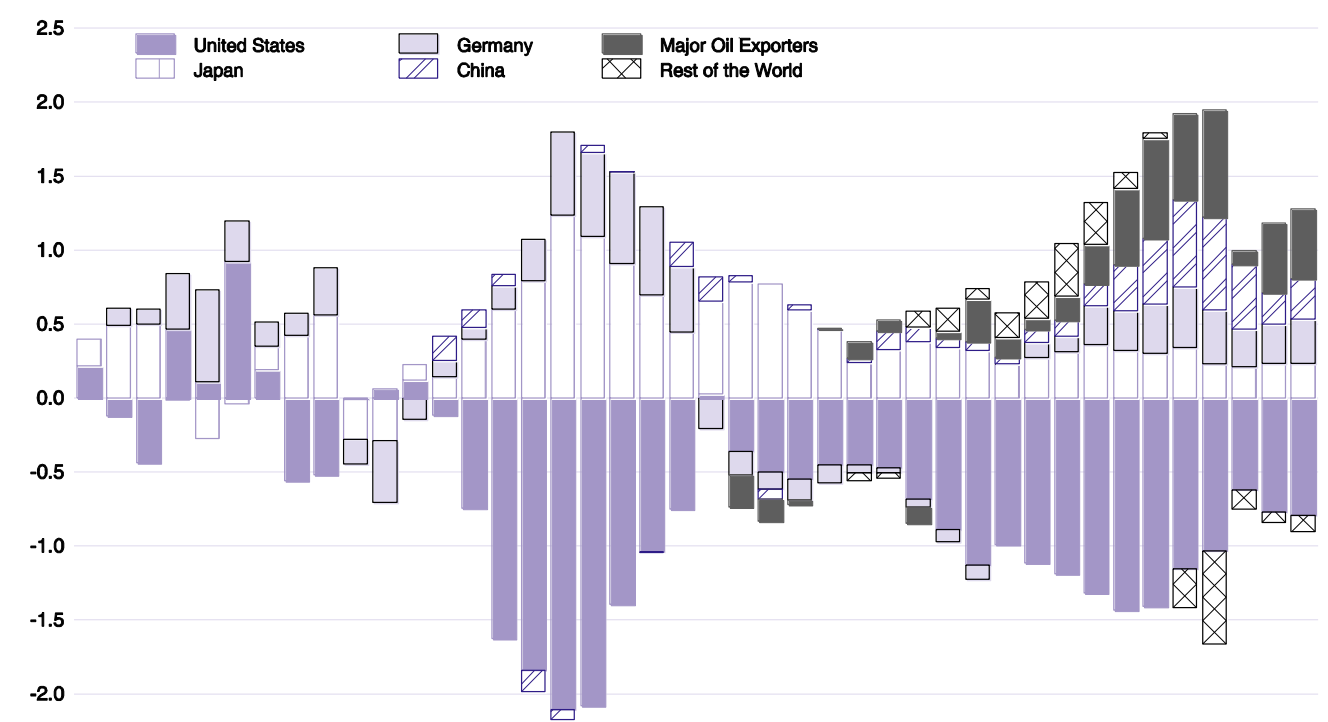

-2.5 197019721974197619781980198219841986198819901992199419961998200020022004200620082010

(*)Data for 2010-11 are projections from the OECD Economic Outlook 87 database.

Source: OECD (Economic Outlook 87) and national sources.

Figure 2 - Net Investment Positions, 1970-2007 In \% of Individual Country GDP

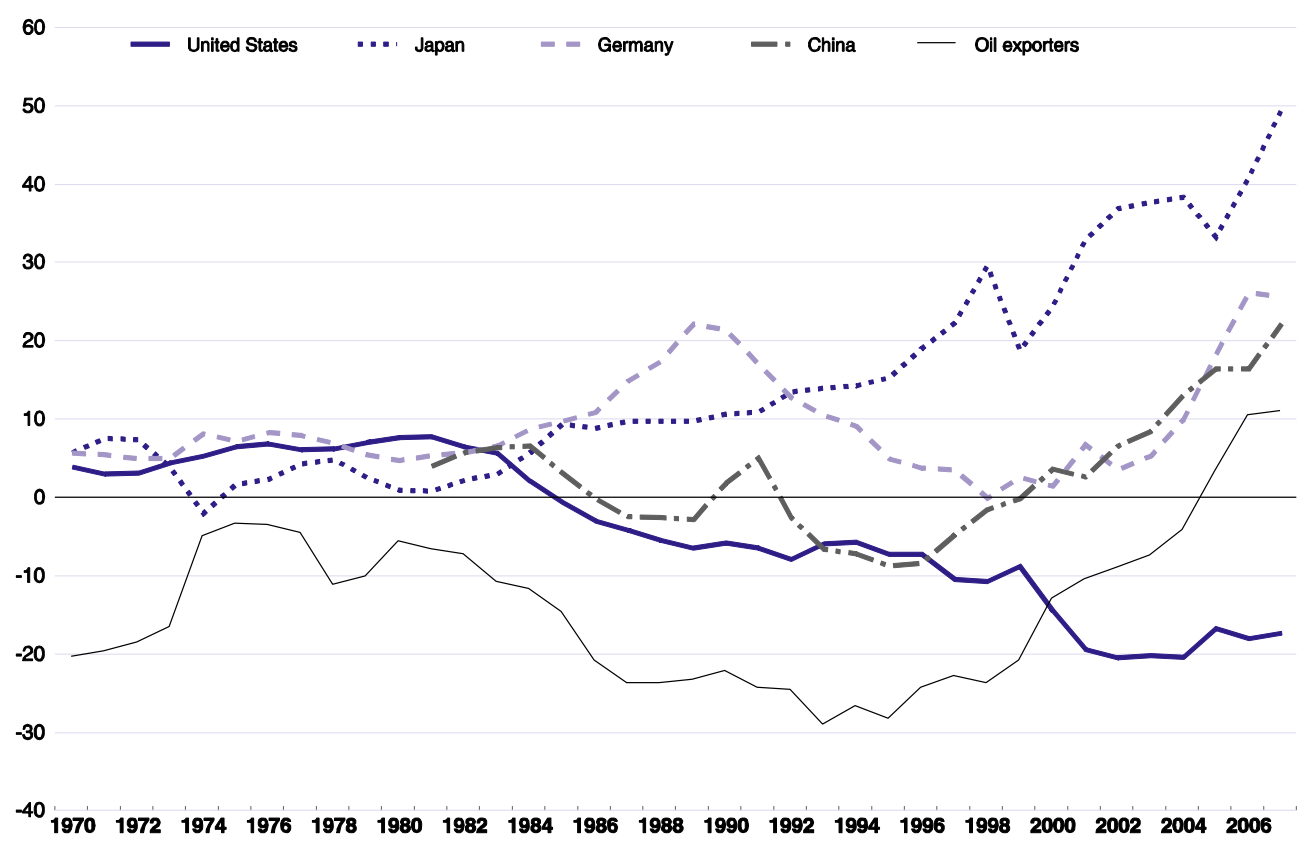

Source: Updated and extended version of the External Wealth of Nations Mark II database developed by Lane and Milesi-Ferretti (2007). 
Consistent with these trends in current account positions, there has been a sustained increase in the net foreign asset positions of the surplus countries. The United States was a net creditor until 1990 but has since then accumulated a net investment deficit of close to $20 \%$ of GDP (Figure 2 ). By contrast, as a result of persistent surpluses, Japan has accumulated a net investment position of close to $50 \%$ of GDP, and China has sustained a positive net investment position since 2000. Germany depleted its accumulated assets in the 1990s following unification as a result of persistent current account deficits, a situation that has since then been reversed.

\subsection{The Effects of the Crisis}

Global imbalances nearly halved during 2009-10 as a result of the crisis, with a marked decline in the United States' deficit and in the surplus of the oil-exporting countries. These developments reflect important variations across countries in the magnitude of current account adjustments (Figure 3) and the composition of these adjustments between private and government balances (Figure 4). In the major surplus countries, such as Germany and Japan, a deterioration of government balances was not matched by a one-to-one improvement in private balances, which led to a fall in these countries' current account surpluses. In the United States, a slight improvement in the current account balance took place on the back of an improvement in the private balance, which more than compensated for a reduction in the government balance. With regard to other countries, changes in the private balance were particularly pronounced in Denmark, Iceland, Ireland, Spain and New Zealand, reflecting substantial deleveraging in the household and corporate sectors during the crisis.

Current account changes during the recession have also reflected sizeable variations across countries in the responses of savings and investment to the crisis. In the major surplus countries, such as Germany and Japan, a fall in national savings accounted for most of the decline in these countries' current account surpluses during 2007-10 (Figure 5). As for the United States, a fall in investment accounted for the lion's share of the improvement in the current account balance over the same period. As for the other countries, reductions in national savings have been particularly large in Ireland, which, coupled with a sharp contraction in investment, contributed to a sizeable reduction in the current account deficit. 
Figure 3 - Net Current Account Positions, 2007 and 2010, \% of Individual Country GDP

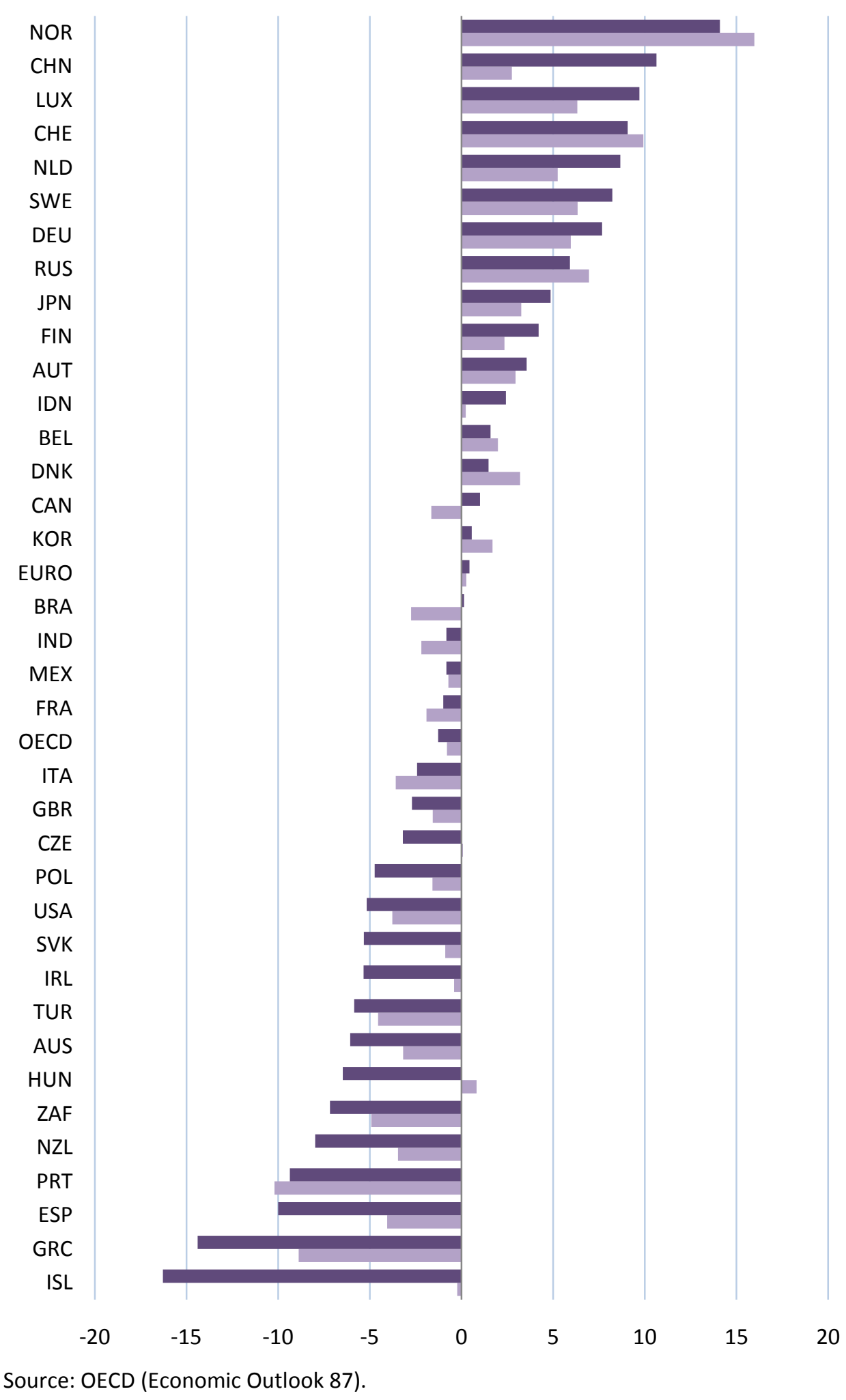


Figure 4 - Decomposition of Changes in Current Account Positions: Private and Government Balances, ${ }^{*}$ 2007-10, in \% of Individual Country GDP

- Current Account Balance

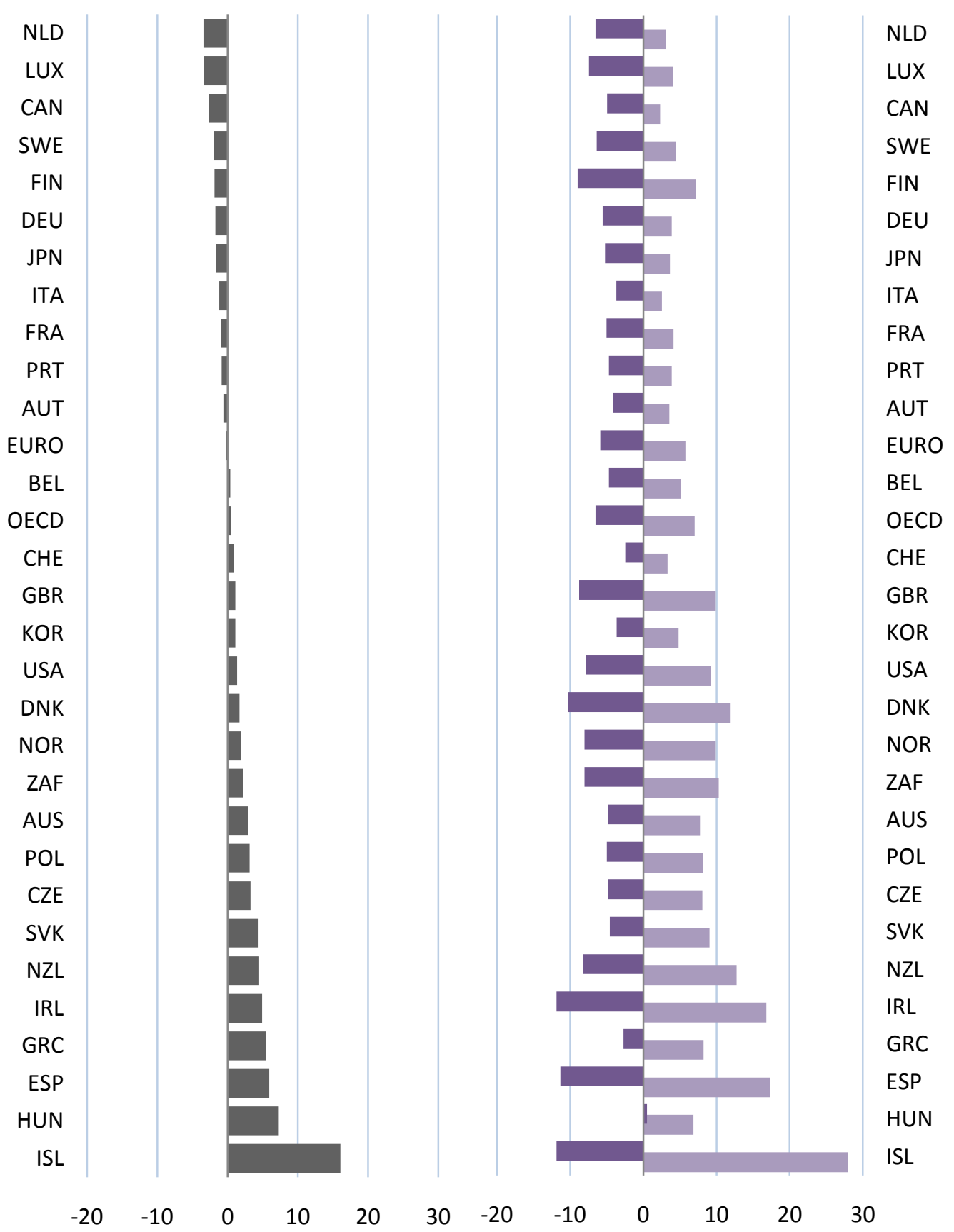

(*) The government balance is defined as the headline budget balance and the private balance is calculated as the difference between the current account balance and the headline budget balance.

Source: OECD (Economic Outlook 87). 
Figure 5 - Decomposition of Changes in Current Account Positions: Saving and Investment, * 2007-10, in \% of Individual Country GDP

Current Account Balance

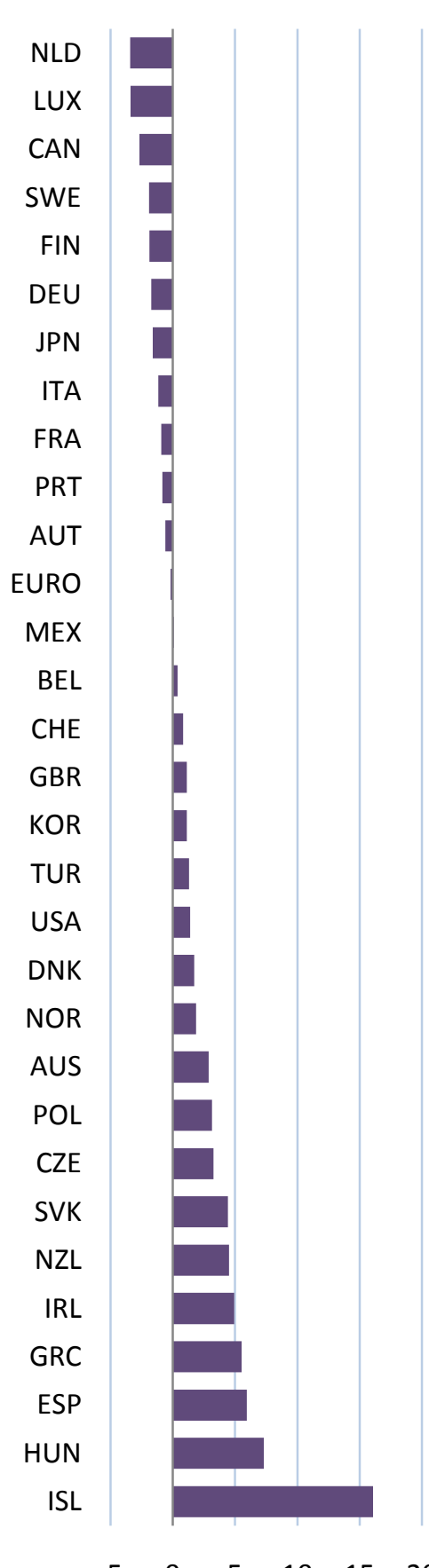

Saving

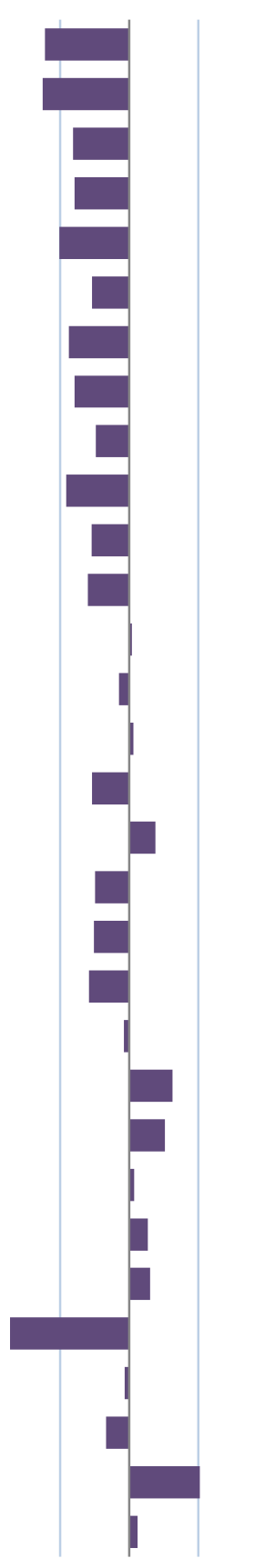

Investment

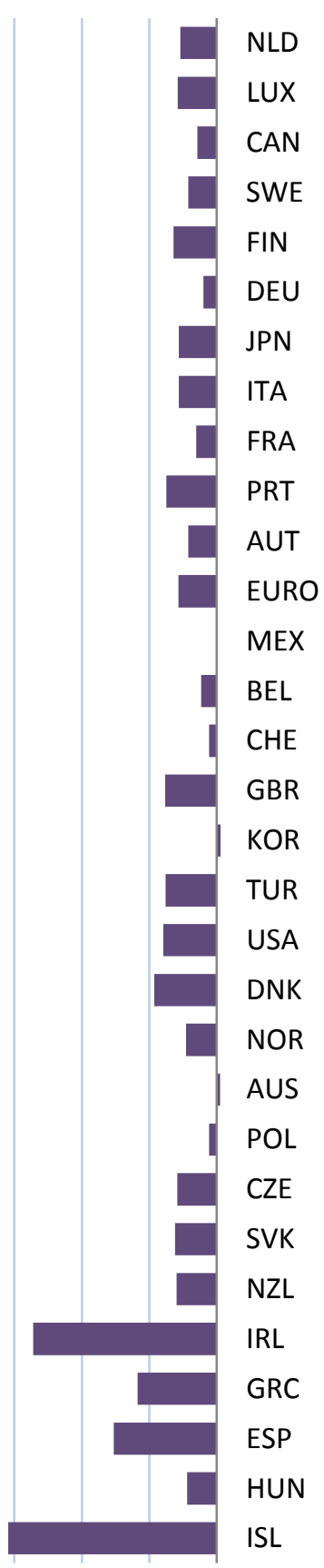

$\begin{array}{llllll}-5 & 0 & 5 & 10 & 15 & 20\end{array}$

$\left({ }^{*}\right)$ Investment is measured as gross fixed capital formation and national saving is calculated as the sum of the current account balance and investment. Source: OECD (Economic Outlook 87). 
Global imbalances are widening again as the global recovery takes hold. The United States' deficit is rising, in part due to the strength of the recovery in that country, with GDP growth outpacing that of the euro-area as a whole. The German surplus is also projected to increase, reflecting the relative exposure of domestic exporters to the gradual upturn in demand for capital goods and the slow recovery of domestic demand. The surplus of the oil-exporting countries is also likely to rise, at least for some time, on the back of the recent upturn in commodity prices. By contrast, China's current account surplus is projected to fall further in 2010, with buoyant domestic demand being accompanied by strong import growth, before rising moderately in 2011 as domestic demand growth eases (OECD, 2010a).

\section{Current Account Reversals: a Few Stylised Facts}

\subsection{The Methodology}

There are different methods for assessing the sustainability of current account positions. In the absence of capital transfers or measurement errors and omissions, a country's current account balance can be defined as:

$$
N F A_{t}-N F A_{t-1} \equiv C A_{t}=r N F A_{t-1}+T B_{t}
$$

where NFA, CA and TB denote, respectively, net foreign assets, the current account balance and the trade (goods and services) balance in per cent of GDP; $r$ is the rate of return on net foreign assets and; and $t$ is a time index.

Equation (1) can be solved forward subject to a no-Ponzi-game transversality condition $\left(\lim _{T \rightarrow \infty}(1+r)^{-T} N F A_{t+T+1}=0\right)$, such that $N F A_{t-1}=-\sum_{j=0}^{\infty}(1+r)^{-(j+1)} T B_{t+j}$. It then follows that the sustainability of current account positions can be assessed by testing for stationarity of CA (in levels) and NFA (in first differences) (Trehan and Walsh, 1991). The implication of non-stationarity is that the CA and NFA series are not mean-reverting, and fluctuations in these series would only converge back to equilibrium in response to exogenous shocks.

\subsection{Testing for Stationarity 4}

The Lee and Strazicich $(1999,2003)$ procedure is used to test for the presence of unit roots in CA (in levels) and NFA (in first differences). The

\footnotetext{
${ }^{4}$ This section draws on de Mello et al. (2010).
} 
two-break Lagrange Multiplier (LM) unit root test statistic can be estimated as follows:

$$
\Delta y_{t}=\delta^{\prime} \Delta Z_{t}+\phi \tilde{S}_{t-1}+u_{t}
$$

where $\tilde{S}_{t}=y_{t}-\tilde{\psi}_{x}-Z_{t} \tilde{\delta}, t=2, \ldots, T, \tilde{\delta}$ are coefficients in the regression of $\Delta y_{t}$ on $\Delta Z_{t}$ for a data generating process defined as $y_{t}=\delta Z_{t}+e_{t}$ and $e_{t}=\beta e_{t-1}+\varepsilon_{t}$ where $Z_{t}$ is a vector of exogenous variables and $\varepsilon_{t}$ is distributed $N\left(0, \sigma^{2}\right)$, and $\tilde{\psi}_{x}$ is given by $y_{1}-Z_{1} \tilde{\delta}$, where $y_{1}$ and $Z_{1}$ are the first observations of $y_{t}$ and $Z_{t}$, respectively. The unit root null hypothesis is described by $\phi=0$, and the LM test statistics are given by $\rho=T \tilde{\phi}$ and $\tilde{\tau}=\mathrm{t}$-statistic testing for the null hypothesis $\phi=0$.

The breaks are determined endogenously through a grid search to be where the test statistic is minimised. Critical values and the asymptotic distributions of the tests are reported in Lee and Strazicich $(1999,2003)$.

This minimum LM test has the advantage of allowing for structural breaks in intercepts and trends in both the null (unit roots with breaks) and alternative (stationarity around breaks) hypotheses and therefore improves upon previous tests that also determine structural breaks endogenously but define the breaks only under the alternative hypothesis, such as that of Zivot and Andrews (1992), which may suffer from spurious rejection problems. Rejection of the Lee-Strazicich null unambiguously implies a trend stationary process. Another advantage of the LeeStrazicich test is that, by identifying structural breaks endogenously, it allows for setting a chronology of current account reversals that are consistent with stationarity in the CA ad NFA series. Instead, the empirical literature typically uses ex-ante definitions of current account reversals based on the size of adjustments in external positions (MilesiFerretti and Razin, 2000; Eichengreen and Adalet, 2005), rather than endogenously determined structural breaks in the relevant series.

We started by allowing for the presence of two breaks in intercepts and trends. If one of the breaks identified on the basis of the two break tests was not found to be significant (in both intercepts and trends), we used instead an alternative version of the test that allows for the presence of a single break. Data on CA are available from the OECD Economic Outlook database and the International Monetary Fund's International Financial Statistics. Data on NFA is obtained from the updated and extended version of the External Wealth of Nations Mark II database developed by Lane and Milesi-Ferretti (2007).

The results, reported in Table 1, show that, first, the hypothesis of a unit root with breaks can be rejected against the alternative of stationarity 
around breaks at the 5\% level for all countries/regions. ${ }^{5}$ The findings are by and large robust to the use of annual data for CA and NFA, as well as annual data at the quarterly frequency for CA to deal with seasonal effects in current account determination. Second, there is some variation in the chronology of breaks across countries and data frequencies. On the basis of the annual data, for which data are available for both CA and NFA, there have been structural breaks in the CA series in 1982-83 (United States, Japan and the oil-exporting countries), 1990-92 (China, United States and the oil-exporting countries), 1996 (China, Germany and Japan) and 2001 (China). As for NFA, there appears to have been structural breaks in 1982 (United States), 1990-92 (China, Germany and the oilexporting countries), 1998-99 (United States, Japan) and 2003 (Japan and Germany). The corresponding chronology based on the quarterly data is by and large consistent with that computed for the annual data, with the exception of the break in 1996 for Japan, which is not identified when the higher-frequency data are used.

The empirical analysis reported above shows that the external positions of the world's major surplus and deficit countries/regions are sustainable around structural breaks (Figure 6). Rejection of the hypothesis of unit roots with breaks in favour of the alternative of stationary around breaks suggests that current account balances are sustainable between breaks but not indefinitely. Sooner or later current account reversals occur to ensure the sustainability of external positions. Failure to account for structural breaks would lead to an erroneous acceptance of the hypothesis of unit roots, which would imply that current account balances are not sustainable. Understanding the characteristics of such breaks and the behaviour of macroeconomic and structural policies around such breaks would therefore shed light of how policy action can help to ensure the sustainability of external positions. ${ }^{6}$

\footnotetext{
${ }^{5}$ The possibility of non-linear dynamics in current account adjustment has also been entertained. For example, Christopoulos and Léon-Ledesma (2010) carried out smooth-transition unit root tests for the United States current account balance and could not reject the null of non-stationarity.

${ }^{6}$ There is a large empirical literature on the determinants of current account balances in individual countries, based on the workhorse inter-temporal models pioneered by Razin (1995) and Obstfeld and Rogoff (1998). Cross-country evidence is also available (Chinn and Prasad, 2003; Chinn and Ito, 2008). However, empirical analysis of the determinants of current account reversals is more limited and focused predominantly on non-OECD countries (Milesi-Ferretti and Razin, 2000; Eichengreen and Adalet, 2005). The literature shows that current account reversals are prompted by changes in the domestic policy stance, essentially fiscal policy, and external shocks, such as sudden stops in financial flows and terms-of-trade shocks.
} 
Table 1 - Current Account Sustainability: Unit Root Tests

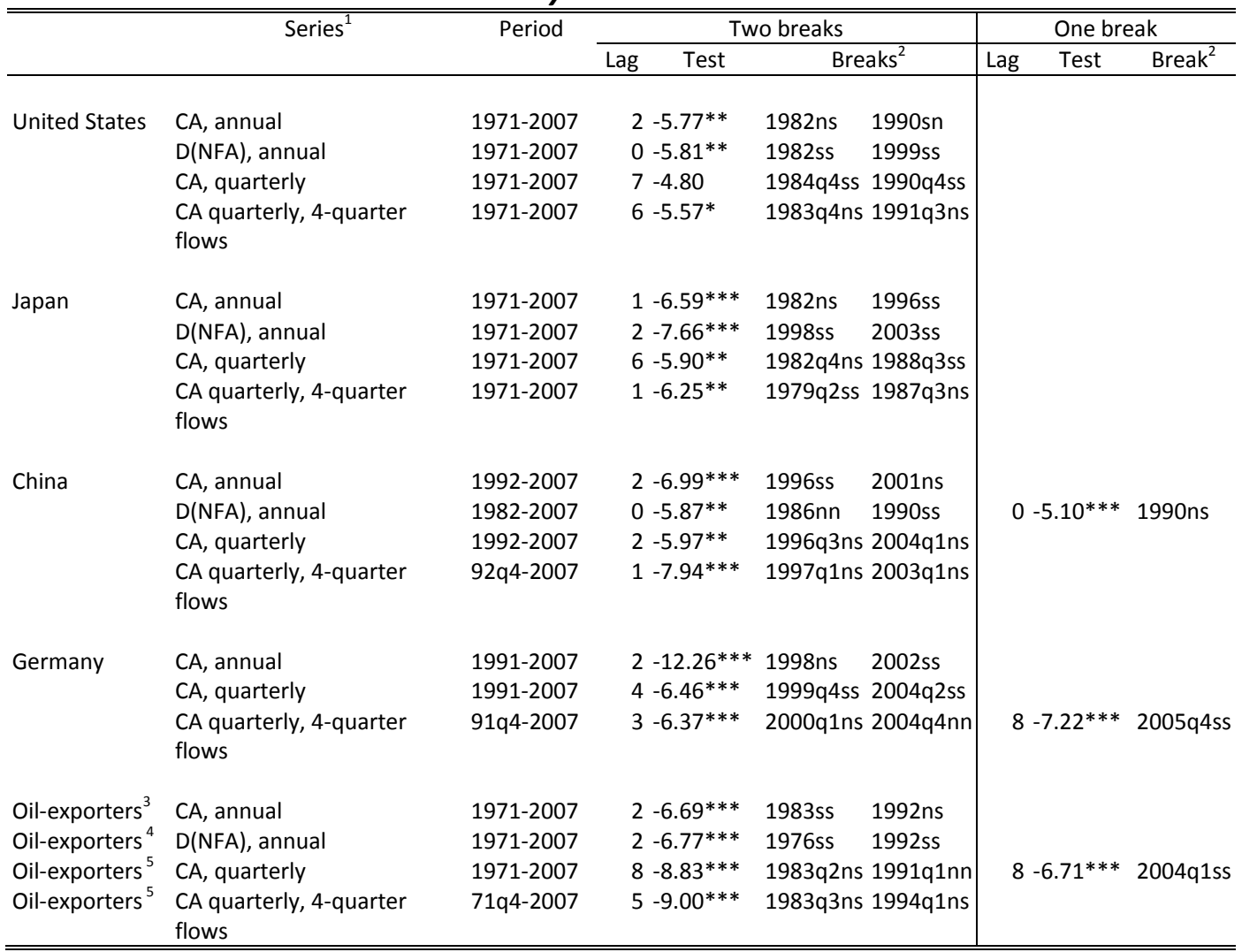

Notes: Critical values for the two- and one-break tests are available from Lee and Strazicich (1999 and 2003). The optimal number of lagged first-differenced terms included in the unit root test to correct for serial correlation is selected according to the general-to-specific procedure of Lee and Strazicich (1999 and 2003) with a maximum number of lags set to 2 and 8 for the annual and quarterly data, respectively. Statistical significance at the 1, 5 and $10 \%$ levels is indicated by ***, ** and $*$, respectively.

1. $C A=$ current account balance (in levels and in per cent of GDP), D(NFA) = net foreign assets (in first differences and in per cent of GDP), 4-quarter flows = flows accumulated over four quarters.

2. The significance of breaks in intercepts and trends is identified by " $n$ " (non-significant) and " $s$ " (significant) at the $10 \%$ level.

3. Includes Canada, Saudi Arabia and Venezuela.

4. Includes Saudi Arabia, Iran, Canada, Norway, Nigeria, Venezuela and Mexico.

5. Includes Canada and Saudi Arabia.

Source: OECD (Economic Outlook 86), IMF (International Financial Statistics), Lane and MilesiFerretti (2007), national sources; and authors' estimations.

The event analysis depicted in Figure 7 for the chronology of structural breaks identified in Annex 1 shows that the behaviour of fiscal policy differs in deficit and surplus countries prior to and after current account reversals. In the United States, the world's largest deficit country, the budget balance deteriorates prior to current account reversals and improves thereafter (a pattern also observed in Japan in the late 1970s break). This suggests that fiscal consolidation may contribute to reducing global imbalances, although the responses of private saving to changes in 
government savings also need to be taken into account (as discussed below). In the surplus countries (Germany, Japan in the late 1980s break, and China, albeit for a short period of time), by contrast, budget balances tend to continue to improve after current account reversals, suggesting that concern about the sustainability of public finances is not a major driver of current account adjustment in these countries.

Figure 6 - Current Account Balances and Structural Breaks, 1970-2007. Based on the structural breaks identified in Table A1.1, in \% of individual country GDP.

United States
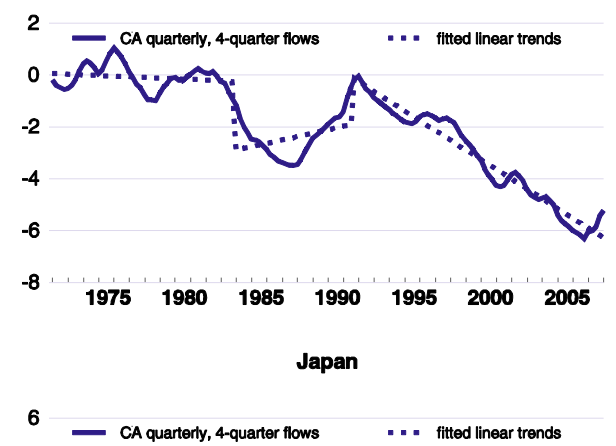

4

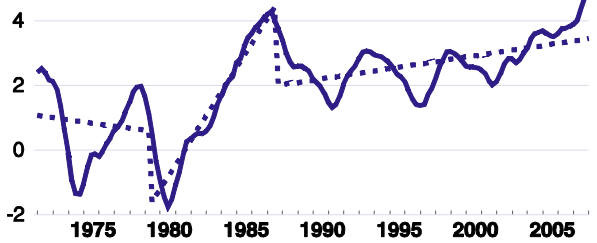

Oll exporters

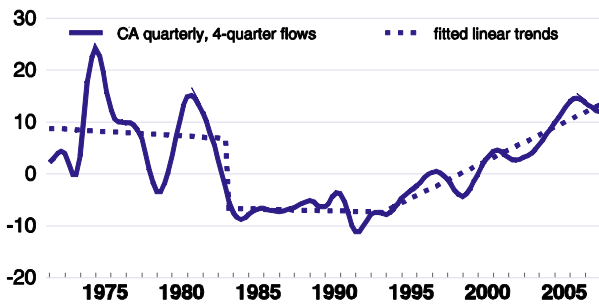

Germany
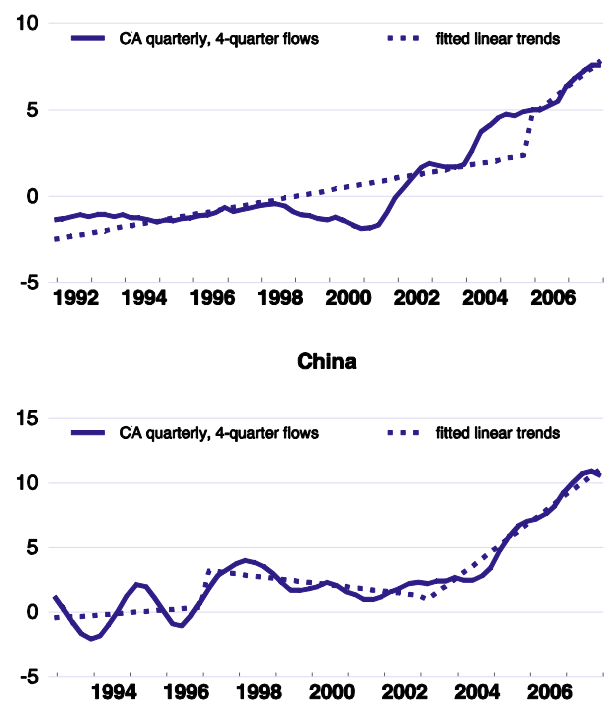

(1) Includes Canada and Saudi Arabia.

Source: (Economic Outlook 87), national sources; and authors' estimations.

Inspection of exchange rate patterns in the vicinity of current account reversals is also instructive. In the United States, structural breaks in that country's current account balance are associated with a continued tradeadjusted nominal appreciation of the US dollar, albeit by a smaller magnitude in the early 1990s episode than in the early 1980s break. In the surplus countries, there is some heterogeneity in exchange rate behaviour around current account reversals, which tend to be followed by a depreciation of the trade-adjusted exchange rate, albeit with some lag in the case of the late 1980s episode in Japan. There nevertheless appears to 
be little change in the exchange rate after reversals in the case of the oilexporting countries and Germany. As for China, exchange rate patterns changed radically between the two episodes of current account reversals depicted in the event analysis.

\section{Figure 7 - An Event Analysis of Current Account Reversals ${ }^{1}$}

First break

Second break

A. Government balance ${ }^{2}$ (rescaled to 0 at $\mathrm{t}_{0}$ )
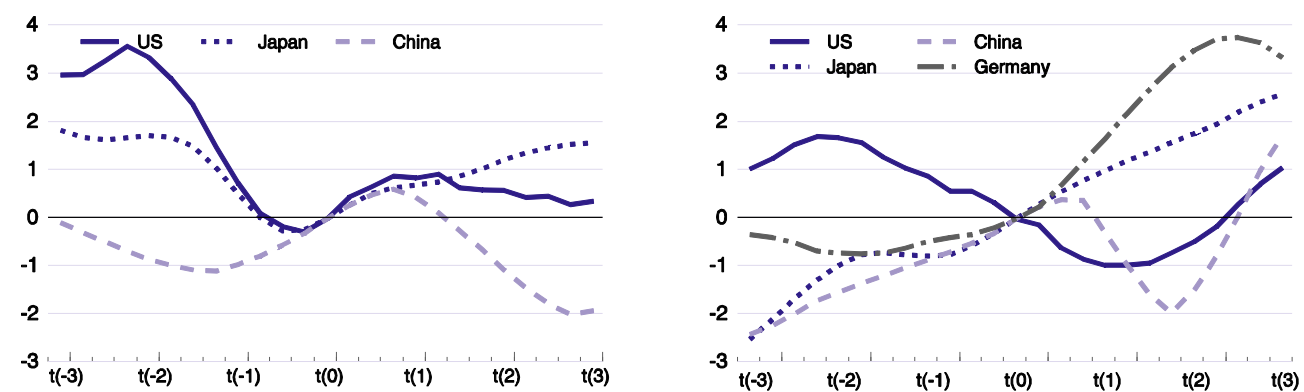

B. Nominal effective exchange rate (rescaled to 100 at $t_{0}$ )
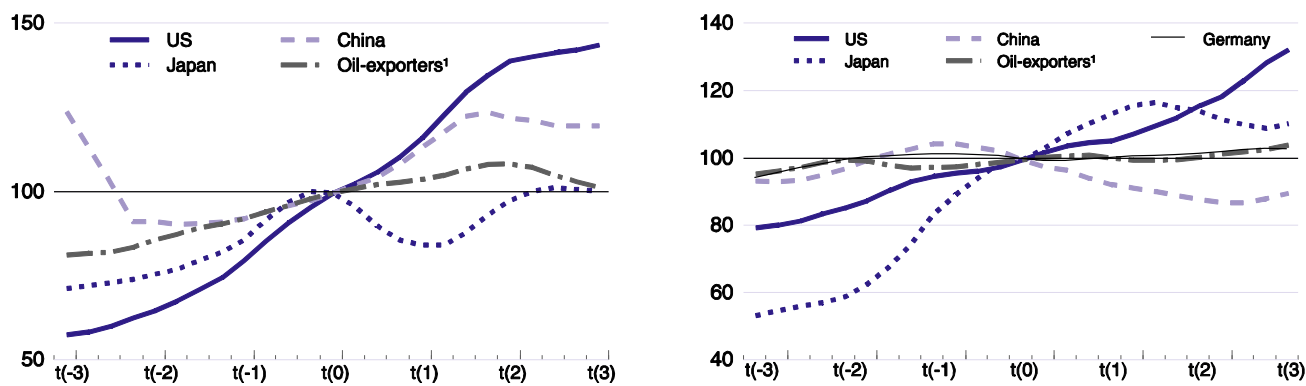

C. Potential output growth (annualised quarterly rates, rescaled to 0 at $\mathbf{t}_{0}$ )
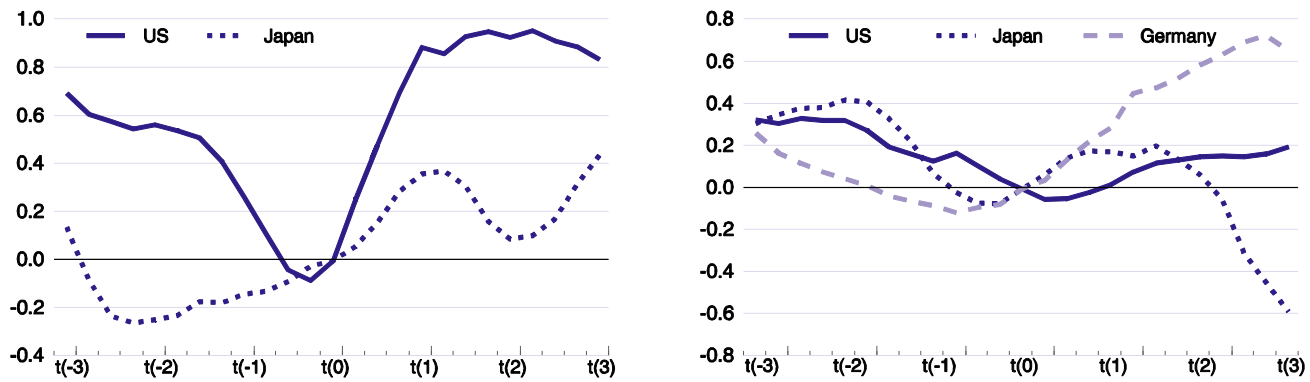

First break: $t_{0}=1983 q 4$ for the United States, 1979q2 for Japan, 1997q1 for China, and 1983q3 for the oil-exporting countries

Second break: $t_{0}=1991 q 3$ for the United States, 1987q3 for Japan, 2003q1 for China, 2005q4 for Germany and 1994q1 for the oil-exporting countries

(1) Based on the structural breaks identified in Table A1.1using annual data for the current account-to-GDP ratio at the quarterly frequency.

(2) Data are not available for the oil-exporting countries.

(3) Includes Canada and Saudi Arabia.

Source: OECD (Economic Outlook 87), national sources; and authors' calculations. 
The longer-term repercussions of current account reversals can be gauged by looking at patterns in potential output growth around structural breaks. Potential output appears to accelerate in the aftermath of corrections in external positions in deficit and surplus countries alike, a development that is nevertheless short-lived, as the post-reversal growth impetus appears to ebb after a year. This suggests that structural reform is needed to entrench the short-term impact of regained external sustainability on potential growth.

\section{Resolving Global Imbalances in a Durable Manner}

\subsection{Policy Simulations}

The stylized facts highlighted by the event analysis of current account reversals need to be assessed in greater detail. Recent analysis carried out by the OECD (OECD, 2010a), based on the Organisation's Global Model, ${ }^{7}$ illustrates the effect of different policy scenarios for fiscal consolidation and the implementation of structural reform on global imbalances. The premises underpinning the different policy scenarios are described in Annex 1. The results of the simulations are reported in Table 2.

\subsection{Business-as-usual Scenario}

In a baseline scenario characterised by the closure of output gaps from their current levels and relatively unambitious fiscal policy in OECD countries focused on stabilising government indebtedness in relation to GDP, global imbalances would re-emerge over the medium term, while remaining below the levels prevailing immediately before the crisis. The current account deficit of the United States would rise to just over $4 \%$ of GDP over the medium-to-longer term (2015-25), while the Chinese surplus would widen gradually to about 5.5 per cent of GDP in 2025. The current account surplus of Japan would fall gradually to about 2\% of GDP in 2025 as a result of population ageing. The current-account balance of the euro area would rise to about $1.3 \%$ of GDP at the end of the simulation period, although much larger imbalances would remain within the area.

\footnotetext{
${ }^{7}$ The OECD Global Model combines short-term Keynesian dynamics with consistent long-run neo-classical supply-side responses. It also features stock-flow consistency, with explicit modelling of domestic and international assets, liabilities and associated income streams and so gives prominence to wealth and the role of asset prices in the transmission of international shocks. The Model identifies the United States, the euro area and Japan with the remainder of the OECD divided in two regions. As for the non-OECD area, China is identified as a single block and the remainder of the non-OECD area is divided in three geographical regions. For further details see Hervé et al. (2010).
} 
Table 2 - Heritage Impact of Fiscal Consolidation, Exchange Rate Flexibility and Structural Reform on External Positions, ${ }^{1}$ in Per Cent of GDP

\begin{tabular}{|c|c|c|c|c|c|c|c|}
\hline & \multicolumn{4}{|c|}{ Current account balance } & \multicolumn{3}{|c|}{$\begin{array}{l}\text { Difference from baseline } \\
\text { scenario }\end{array}$} \\
\hline & 2008 & 2011 & 2015 & 2025 & 2011 & 2015 & 2025 \\
\hline \multicolumn{8}{|l|}{ United States } \\
\hline Baseline & -4.9 & -4.0 & -4.1 & -4.2 & $\ldots$ & $\ldots$ & $\ldots$ \\
\hline Plus fiscal consolidation & -4.9 & -3.7 & -4.0 & -4.2 & 0.3 & 0.1 & 0.0 \\
\hline Plus exchange rate response & -4.9 & -3.6 & -3.6 & -3.5 & 0.4 & 0.5 & 0.7 \\
\hline Plus structural reform & -4.9 & -3.5 & -2.8 & -1.0 & 0.5 & 1.3 & 3.2 \\
\hline \multicolumn{8}{|l|}{ Japan } \\
\hline Baseline & 3.3 & 3.5 & 3.1 & 2.0 & $\cdots$ & $\ldots$ & $\ldots$ \\
\hline Plus fiscal consolidation & 3.3 & 3.8 & 4.3 & 2.7 & 0.3 & 1.2 & 0.7 \\
\hline Plus exchange rate response & 3.3 & 4.0 & 4.6 & 3.5 & 0.5 & 1.5 & 1.5 \\
\hline Plus structural reform & 3.3 & 3.9 & 4.8 & 2.9 & 0.4 & 1.7 & 0.9 \\
\hline \multicolumn{8}{|l|}{ Euro area } \\
\hline Baseline & -0.8 & 0.8 & 1.1 & 1.3 & $\ldots$ & $\ldots$ & $\ldots$ \\
\hline Plus fiscal consolidation & -0.8 & 1.1 & 0.4 & 1.4 & 0.3 & -0.7 & 0.1 \\
\hline Plus exchange rate response & -0.8 & 1.1 & 0.7 & 1.7 & 0.3 & -0.4 & 0.4 \\
\hline Plus structural reform & -0.8 & 1.2 & 0.7 & 1.8 & 0.4 & -0.4 & 0.5 \\
\hline \multicolumn{8}{|l|}{ China } \\
\hline Baseline & 9.4 & 3.4 & 4.0 & 5.5 & $\cdots$ & $\ldots$ & $\ldots$ \\
\hline Plus fiscal consolidation & 9.4 & 3.2 & 3.9 & 5.3 & -0.2 & -0.1 & -0.2 \\
\hline Plus exchange rate response & 9.4 & 2.8 & 3.3 & 4.7 & -0.6 & -0.7 & -0.8 \\
\hline Plus structural reform & 9.4 & 2.3 & 2.2 & 3.1 & -1.1 & -1.8 & -2.4 \\
\hline \multicolumn{8}{|l|}{ Other non-OECD Asia } \\
\hline Baseline & 2.7 & 1.9 & 1.7 & 1.5 & $\cdots$ & $\ldots$ & $\ldots$ \\
\hline Plus fiscal consolidation & 2.7 & 1.3 & 1.6 & 1.2 & -0.6 & -0.1 & -0.3 \\
\hline Plus exchange rate response & 2.7 & 1.5 & 1.3 & 0.7 & -0.4 & -0.4 & -0.8 \\
\hline Plus structural reform & 2.7 & 1.5 & 0.7 & -0.7 & -0.4 & -1.0 & -2.2 \\
\hline
\end{tabular}

(1) The underlying assumptions are described in Annex 2.

Source: OECD (2010a).

\subsection{Fiscal Consolidation and Associated Exchange-rate Adjustments}

The effect of fiscal consolidation on global imbalances depends to a large extent on how private saving responds to changes in government saving. Empirical analysis for OECD countries suggests that, contrary to the predictions based on Ricardian Equivalence, only about one-half of increases in government saving are offset by a reduction in private saving in the short term, against about two-thirds in the long term (de Mello et al. 2004). Of course, the impact on global imbalances of fiscal consolidation in individual countries abstracts from spillover effects associated with simultaneous consolidation in a large number of countries. 
To be sure, an alternative scenario simulated using the OECD Global Model takes into account sufficient fiscal consolidation starting in 2011 to reduce government debt-to-GDP ratios in 2025 to their pre-crisis levels (except for Japan) and some consequent depreciation of OECD currencies vis-à-vis their non-OECD counterparts. The simulations results, also reported in Table 1, suggest that fiscal consolidation has only limited impact on external imbalances, in part because all OECD economies engage in consolidation simultaneously.

In addition, fiscal consolidation would affect OECD currencies, which would likely depreciate relative to the currencies of non-OECD countries. This adjustment in exchange rates would reduce the current account surpluses of China and other non-OECD Asian countries by about $1 / 2$ percentage point of GDP and reduce the US deficit by a similar amount relative to fiscal consolidation scenario.

\subsection{Structural reform}

It is difficult to be sure about the magnitude and direction of the impact of structural reforms on a country's external current account position. Reforms to product and labour market regulations, as well as to tax systems, affect savings and investment behaviour through demand- and supply-side channels that often interrelated and mutually reinforcing. The net effect of reforms therefore depends on the instruments used and the framework conditions prevailing in individual countries. Possible reform packages are discussed in Annex 2.

A simulation of the impact on external positions of a set of stylised structural reforms that would reduce (raise) savings in surplus (deficit) countries, especially China and dynamic non-OECD countries in Asia, and reduce structural unemployment in the euro area, underscores the importance of such reforms in reducing global imbalances in a sustained manner. In particular, in the structural reform scenario, the external deficit of the United States would be reduced by over $2.5 \%$ of GDP and the Chinese surplus would fall by more than $1.5 \%$ of GDP relative to the scenario with fiscal consolidation and attendant exchange- rate adjustments. The surplus of other dynamic Asian economies would contract by about 1.5 percentage point of GDP.

\section{Implications for Capital Flows in the Post-crisis Scenarios}

The global crisis and the ensuing recovery are too recent to be picked up as a structural break by the unit root tests. But, given the magnitude of the current account reversal that took place in 2008-10, it is likely that a 
structural break will be identified around 2009-10 as new data become available. Lessons from previous current account reversals drawn from the event analysis, coupled with the policy simulations reported above, provide insights into the types of macroeconomic and structural policies that could bring about a sustained reduction in global imbalances. While such imbalances can be reduced through appropriate policies, they will not be (and indeed should not be) completely eliminated. A new configuration of external positions among the world's main economic areas would therefore have implications for the flows of capital between surplus and deficit countries. It is difficult to ascertain the changes in the magnitude and direction of capital flows that would follow from the implementation of specific structural reforms in the years to come, but a few stylised facts can be highlighted. For example:

- Fiscal consolidation tends to follow current account reversals on the basis of previous experience and will be much needed in some countries as a result of a massive build-up of government debt related to the global crisis. A reduction over the years in the supply of government bonds in (mostly advanced) countries that currently have high debt and/or budget deficits could therefore lead to a rebalancing of capital flows from surplus to deficit countries towards corporate bonds, equity and/or foreign direct investment, which could be growth-enhancing. Of course, for such a rebalancing to take place, the effects of changes in the rates of return of riskless assets (government bonds) and private sector securities on demand for those assets would need to be taken into account.

- Greater exchange-rate flexibility in those emerging-market economies that currently have large current account surpluses could also lead to a change in international capital flows. In the event of a revaluation of their exchange-rate parities, surplus countries whose currencies are currently pegged or tightly linked to the U.S. dollar, such as China and the oil-exporting countries, would no longer need to accumulate large amounts of international reserves in the form of U.S. government bonds. To the extent that lower demand for U.S. bonds is matched at least in part by rising investment in corporate bonds, equity and FDI in deficit countries, a combination of fiscal consolidation in deficit countries with greater exchange-rate flexibility in surplus countries could be growth-enhancing.

- Structural reform to lift global potential output after the crisis could have potentially strong effects on the composition of capital flows, especially if combined with fiscal consolidation in deficit countries and greater exchange rate flexibility in emerging market economies with large current account surpluses. For example, initiatives that could lead to higher household savings in the United States (for example, through 
the elimination of tax deductibility of mortgage payments and greater reliance on consumption taxes) would affect the size and composition of insurance and pension fund portfolios. A liberalisation of entry restrictions in sheltered sectors in surplus countries, such as Germany and Japan, could create opportunities for foreign investment in those countries. On the other hand, reforms in emerging-market economies with large current account surpluses aimed at reducing household savings by strengthening social safety nets and/or corporate savings through financial market reform would increase the attractiveness of investing in such countries, thus limiting capital outflows towards advanced economies.

\section{Conclusions}

Global imbalances have shrunk considerably in the aftermath of the global crisis and the recession that followed it but are likely to re-emerge during the recovery. Large swings in capital flows are often needed to restore the sustainability of external positions in surplus and deficit countries alike. An event analysis based on a chronology of current account reversals needed to ensure that the ratios of current account balances to GDP in the world's main economic areas are stationary highlights a few stylised facts about the behaviour of macroeconomic and structural policies around structural breaks. The global financial and economic crisis could clearly be associated with a structural break in external positions, but the crisis is too recent to be picked up by the unit root test. Nevertheless, policy simulations based on the OECD Global Model allow for a comparison of the evolution of current account imbalances in the medium-to-longer term according to different scenarios for fiscal consolidation, exchange rate movements and structural reform. The simulations highlight the scope for raising long-term potential output and reducing global imbalances through a combination of fiscal consolidation to bring government indebtedness back to pre-crisis levels over time and structural reforms to reduce consumption in deficit countries and savings in surplus countries.

The different policy scenarios have implications for the direction and composition of long-term capital flows that will be needed to finance global imbalances in the years to come. While a detailed analysis of such implications requires further investigation, a few stylized facts can be emphasised. First, following fiscal consolidation in many advanced economies, capital flows from surplus to deficit countries could also imply a move away from government securities towards corporate bonds, equity and/or foreign direct investment, which could be growth-enhancing. 
Second, with greater exchange-rate flexibility emerging-market economies with large current account surpluses would accumulate smaller amounts of international reserves in the form of U.S. government bonds, and therefore redirect their capital outflows to different investment modalities. Third, structural reforms, such as a liberalisation of entry restrictions in sheltered sectors in advanced surplus countries, could create opportunities for foreign investment in those countries. By the same token, reforms in surplus emerging-market economies aimed at reducing household savings through a strengthening of safety nets and/or corporate savings through financial market reform would unleash opportunities for investment in those countries, thus limiting capital outflows towards advanced economies. 


\section{References}

Alesina, A., Ardagna, S., Perotti, R., \& Schiantarelli, F. (2002). Fiscal Policy, Profits and Investment. American Economic Review, 92(3), 571-589. doi:10.1257/00028280260136255

Alesina, A., Ardagna, S., Nicoletti, G., \& Schiantarelli, F. (2005). Regulation and Investment. Journal of the European Economic Association, 3(4), 791825. doi:10.1162/1542476054430834

Baldacci, E., Callegari, G., Coady, D., Ding, D., Kumar, M., Tommasino, P., \& Woo, J. (2010). Public Expenditures on Social Programs and Household Consumption in China, IMF Working Papers 10/69. Washington, D.C.: International Monetary Fund.

Barnett, S., \& Brooks, R. (2010). China: Does Government Health and Education Spending Boost Consumption?, IMF Working Papers 10/16. Washington, D.C.: International Monetary Fund.

Bernanke, B. (2005). The Global Saving Glut and the U.S. Current Account, remarks at the Sandridge Lecture, Virginia Association of Economics, Richmond, VA.

Caballero, R.J., Farhi, E., \& Gourinchas, P.O. (2008). An Equilibrium Model of Global Imbalances and Low Interest Rates. American Economic Review, 98(1), 358-393. doi:10.1257/aer.98.1.358

Cheung, C., Furceri, D., \& Rusticelli, E. (2010). Structural and Cyclical Factors Behind Current Account Balances. OECD Economics Department Working Papers 775. Paris: OECD, Economics Department.

Chinn, M.D., \& Ito, H. (2008). Global Current Account Imbalances: American Fiscal Policy versus East Asian Savings. Review of International Economics, 16(3), 479-498. doi:10.1111/j.1467-9396.2008.00741.x

Chinn, M.D., \& Prasad, E.S. (2003). Medium-term Determinants of Current Accounts in Industrial and Developing Countries: An Empirical Exploration. Journal of International Economics, 59(1), 47-76. doi:10.1016/S0022-1996(02)00089-2

Christopoulos, D., \& Léon-Ledesma, M. (2010). Current Account Sustainability in the US: What Did we Really Know about It? Journal of International Money and Finance, 29(3), 442-459. doi:10.1016/j.jimonfin.2009.06.014

de Mello, L., Kongsrud, P.M., \& Price, R. (2004). Saving Behaviour and the Effectiveness of Fiscal Policy. OECD Economics Department Working Papers 397. Paris: OECD, Economics Department. 
de Mello, L., \& Padoan, P.C. (2010). Promoting Potential Growth: The Role of Structural Reform. OECD Economics Department Working Papers 793. Paris: OECD, Economics Department.

de Mello, L., Padoan, P.C., \& Rousova, L. (2010). The Sustainability of Global Imbalances in Current Account Balances. OECD Economics Department Working Papers 813. Paris: OECD, Economics Department.

de Serres, A., \& Pelgrin, F. (2002). The Decline in Private Saving Rates in the 1990s in OECD Countries: How Much Can be Explained by NonWealth Determinants? OECD Economics Department Working Papers 344. Paris: OECD, Economics Department.

Eichengreen, B., \& Adalet, M. (2005). Current Account Reversals: Always a Problem? NBER Working Paper 11634. Cambridge, MA: NBER.

Feng, J., He, L., \& Sato, H. (2009). Public Pension and Household Saving: Evidence from China. Bank of Finland Discussion Paper, 2-2009, Helsinki: Bank of Finland.

Furceri, D., \& Mourougane, A. (in press). The Influence of Age Structure on Saving and Social Spending. ADBI Working Paper.

Gourinchas, P.O., \& Rey, H. (2005). From World Banker to World Venture Capitalist: US External Adjustment and the Exorbitant Privilege. NBER Working Paper 11563. Cambridge, MA: NBER.

Herd, R., Pigott, C., \& Hill, S. (2010). China's Financial Sector Reforms. OECD Economics Department Working Papers 747. Paris: OECD, Economics Department.

Hervé, K., Pain, N., Richardson, P., Sédillot, F., \& Beffy, P.O. (2010). The OECD's New Global Model. OECD Economics Department Working Papers 768. Paris: OECD, Economics Department.

Kennedy, M., \& Sløk, T. (2005). Structural Policy Reforms and External Imbalances. OECD Economics Department Working Papers 415. Paris: OECD, Economics Department.

Lane, P.R., \& Milesi-Ferretti, G.M. (2007). The External Wealth of Nations Mark II: Revised and Extended Estimates of Foreign Assets and Liabilities, 1970-2004. Journal of International Economics, 73(2), 223-250. doi:10.1016/j.jinteco.2007.02.003

Lee, J., \& Strazicich, M.C. (1999). Minimum LM Unit Root Test. Faculty Research Paper, No. 9932. Orlando, FL: Department of Economics, University of Central Florida.

Lee, J., \& Strazicich, M.C. (2003). Minimum Lagrange Multiplier Unity Root Test with Two Structural Breaks. Review of Economics and Statistics, 85(4), 1082-189. doi:10.1162/003465303772815961 
Mendoza, E.G., Quadrini, V., \& Rios-Rull, J.V. (2007). Financial Integration, Financial Deepness and Global Imbalances. NBER Working Paper 12909. Cambridge, MA: NBER.

Milesi-Ferretti, G.M., \& Razin, A. (1997). Sharp Reductions in Current Account Deficits: An Empirical Investigation. NBER Working Paper 6310. Cambridge, MA: NBER.

Milesi-Ferretti, G.M., \& Razin, A. (2000). Current Account Reversals and Currency Crises, Empirical Regularities. In Krugman, P. (Ed.), Currency Crises (pp.285-326). Chicago: University of Chicago Press,.

Nicoletti, G., Golub, S., Hajkova, D., Mirza, D., \& Yoo, K. (2003). Policies and International Integration: Influences on Trade and Foreign Direct Investment. OECD Economics Department Working Papers 359. Paris: OECD, Economics Department.

Obstfeld, M., \& Rogoff, K. (2009). Global Imbalances and the Financial Crisis: Products of Common Causes. Paper prepared for the Federal Reserve Bank of San Francisco Asia Economic Policy Conference, Santa Barbara, CA, October 18-20, 2009.

Obstfeld, M., \& Rogoff, K. (1998). Risk and Exchange Rates. NBER Working Paper 6694. Cambridge, MA: NBER.

OECD. (2003). The Sources of Economic Growth in OECD Countries. Paris: OECD.

OECD. (2008). Economic assessment of Indonesia. Paris: OECD.

OECD. (2009a). OECD Economic Outlook, No. 86. Paris: OECD.

OECD. (2009b). Economic Survey of Brazil. Paris: OECD.

OECD. (2010a). OECD Economic Outlook, No. 87. Paris: OECD.

OECD. (2010b). Going for Growth. Paris: OECD.

OECD. (2010c). Economic Survey of Germany. Paris: OECD.

OECD. (2010d). Economic Survey of China. Paris: OECD.

Qu, Z., \& Perron. P. (2007). Estimating and Testing Structural Changes in Multivariate Regressions. Econometrica, 75(2), 459-502. doi:10.1111/j.1468-0262.2006.00754.x

Razin, A. (1995). The Dynamic-Optimizing Approach to the Current Account: Theory and Evidence. In Kenen, P.B. (Ed.), Understanding Interdependence: The Macroeconomics of the Open Economy (pp.169-198). Princeton: Princeton University Press.

Schwellnus, C., \& Arnold, J. (2008). How do Taxes Affect Investment and Productivity? An Industry-Level Analysis of OECD Countries. OECD Economics Department Working Papers 656. Paris: OECD, Economics Department. 
Trehan, B., \& Walsh, C. (1991). Testing the Intertemporal Budget Constraint: Theory and Applications to the US Federal Budget Deficits and Current Account Deficits. Journal of Money, Credit and Banking, 23(2), 206-223. doi:10.2307/1992777

Vartia, L. (2008). Do Corporate Taxes Reduce Productivity and Investment at the Firm Level? Cross-Country Evidence from the Amadeus Dataset. OECD Economics Department Working Papers 641. Paris: OECD, Economics Department.

Zivot, E., \& Andrews, D.W.K. (1992). Further Evidence on the Great Crash, the Oil-Price Shock and the Unit Root Hypothesis. Journal of Business and Economic Statistics, 10(3), pp. 251-270. doi:10.2307/1391541 


\section{Annex 1. Global Imbalances: Simulation of Policy Scenarios ${ }^{1}$}

\section{Baseline Scenario}

The following assumptions are made in the baseline scenario for the period 2012-25:

- GDP and unemployment. GDP grows at its potential rate after 2025, when the output gap is closed in all OECD countries. Adjustments to potential output (capital, structural unemployment, labour force participation) resulting from the crisis are completed by 2015. For the 2015-25 period, OECD countries experience a slow convergence to annual labour productivity growth of $13 / 4$ per cent per year. Structural unemployment rates return to their pre-crisis levels by 2015, once postcrisis hysteresis has subsided, in those countries with more flexible labour markets and by 2025 in all other countries.

- Prices and exchange rates. Oil and other commodity prices rise by $1 \%$ per year in real terms after 2011. Exchange rates remain unchanged in nominal terms in OECD countries; for other countries an estimated Balassa-Samuelson effect is used as a basis for assumed currency appreciation between 2011 and 2025. The renminbi appreciates gradually by about $20 \%$ in real terms against all currencies through 2025 , with about half of this appreciation being associated with the convergence in GDP per capita over the period.

- Fiscal policy. The underlying primary budget deficit is reduced by $0.5 \%$ of GDP per year for as long as it takes to stabilise the ratio of government debt to GDP over the medium term. In most cases, this pace of fiscal consolidation leads to a further build-up of government debt before it stabilises. There are no further losses to government balance sheets as a result of asset purchases or guarantees made in dealing with the financial crisis. Effects on public budgets from population ageing and continued upward pressures on health spending are not included. Government debt is projected to increase by about 30 percentage points of GDP by 2011 relative to pre-crisis levels and by about a further 20 percentage points of GDP before it stabilises.

- Monetary policy. Interest rates are normalised towards 2015 in order to bring inflation in line with medium-term objectives. For Japan it is assumed that once the output gap has closed and inflation returns to $1 \%$ in 2015 , the target rate of inflation for monetary policy will be fixed at $2 \%$.

\footnotetext{
${ }^{1}$ This Annex draws on OECD (2010a).
} 
- Long-term interest rates. Long-term interest rates increase by 4 basis points (1 basis point for Japan) for every additional percentage point increase in the government debt-to-GDP ratio above $75 \%$ of GDP. The projected 30 percentage-point increase in the government debt-to-GDP ratio by 2011 relative to pre-crisis would add about 125 basis points to OECD long-term interest rates.

- Non-OECD countries. After 2011, emerging-market economies show a slow convergence to US growth rates in per capita income (measured at purchasing power parity). Trade growth in emerging-market economies is determined by a non-OECD trade equations (Pain et al., 2005) with country-specific coefficients taken from regional estimates that reflect structural sources of current account balances (Cheung et al., 2010).

\section{Fiscal Consolidation}

This scenario involves sufficient fiscal consolidation staring in 2011 to reduce government debt-to-GDP ratios in 2025 to the pre-crisis levels prevailing in each region (except for Japan). Due to Japan's high level of indebtedness, only half of the increase in debt in the aftermath of the crisis is reversed by 2025. In addition:

- GDP growth is lower in 2011-12 in all OECD countries due to fiscal consolidation, depending on the extent of the required adjustment, and higher relative to the baseline scenario from 2013 due to the lower interest rates associated with the fall in government indebtedness.

- OECD currencies fall by $10 \%$ relative to their non-OECD counterparts immediately and by a further $10 \%$ over the following ten years in response to the announcement of consolidation.

\section{Structural Reform Scenario}

The scenario combines sufficient fiscal consolidation staring in 2011 to reduce government debt-to-GDP ratios in 2025 to the pre-crisis levels prevailing in each region (except for Japan) and the attendant effects on exchange rate parities between OECD and non-OECD countries, as well as a set of stylised structural reforms, including: an improvement of financial market regulation, the elimination of distortionary tax incentives and the pricing of environmental externalities of fossil fuel use in the United States; pro-competition product and labour market reforms that would boost potential growth and reduce structural unemployment in the euro area; an easing of product market regulations and reforms to deepen financial markets in Japan; and a combination of policy reforms to improve social safety nets and expand the provision of health care, facilitate access of households to credit and strengthen the business and financial environments in China and other non-OECD Asian economies. 
The following assumptions are made to take these structural reforms into account in the simulations over the period 2012-25:

- Savings. Private and public saving is lowered by 3\% of GDP in China and other non-OECD Asian economies. Private demand is raised by $2 \%$ of GDP in Japan. Private saving is raised by $1 \%$ of GDP in the United States. These changes are phased in over eight years beginning from 2011.

- Unemployment. The structural unemployment rate is reduced in the euro area by 2 percentage points over the next eight years to bring it more into line with the average across other OECD countries.

- Exchange rates. Exchange rates adjust to changes in domestic saving. In particular, the renminbi appreciates by $20 \%$ and the US dollar depreciates by $10 \%$ over two years. These adjustments allow for the impact on GDP of lower (higher) private savings in China (United States) to be compensated by lower (higher) net exports. 


\section{Annex 2. Possible Structural Reform Packages}

The structural reform scenario discussed in the text is stylised in that it takes the outcomes of structural reforms on savings and unemployment in surplus and deficit countries and factors in the attendant exchange rate effects.

Table A2.1 - Implementation of Going for Growth priorities in OECD countries, 2005-09

\begin{tabular}{|c|c|c|}
\hline & \multicolumn{2}{|c|}{ Action taken $^{1}$} \\
\hline & Surplus countries $^{2}$ & Deficit countries $^{2}$ \\
\hline \multicolumn{3}{|l|}{ Product market regulations } \\
\hline $\begin{array}{l}\text { Reduce entry barriers in services } \\
\text { and/or industries in general }\end{array}$ & Austria, Japan, Korea & France, Italy, Poland \\
\hline Reduce entry barriers in network & Germany, Netherlands*, & Australia, Greece, Hungary, \\
\hline industries & Switzerland & $\begin{array}{l}\text { Ireland, Mexico, New Zealand, } \\
\text { Portugal }\end{array}$ \\
\hline $\begin{array}{l}\text { Reduce entry barriers in professional } \\
\text { services }\end{array}$ & $\begin{array}{l}\text { Austria, Canada, Germany, } \\
\text { Switzerland* }\end{array}$ & \\
\hline $\begin{array}{l}\text { Reduce entry barriers in retail } \\
\text { distribution }\end{array}$ & Belgium, Denmark, & France, Ireland* \\
\hline Reduce administrative burdens & $\begin{array}{l}\text { Austria*, Belgium*, Denmark, } \\
\text { Netherlands* }\end{array}$ & $\begin{array}{l}\text { Czech Republic, Greece*, } \\
\text { Hungary*, Turkey* }\end{array}$ \\
\hline Reform corporate governance & & Italy* \\
\hline $\begin{array}{l}\text { Reduce the scope for public ownership } \\
\text { Labour market regulations }\end{array}$ & Sweden* & Turkey* \\
\hline Reform disability and sickness benefits & $\begin{array}{l}\text { Denmark, Netherlands, Norway, } \\
\text { Sweden, Switzerland* }\end{array}$ & $\begin{array}{l}\text { Australia, Hungary, Poland*, } \\
\text { United Kingdom }\end{array}$ \\
\hline $\begin{array}{l}\text { Review wage formation or minimum } \\
\text { cost of labour }\end{array}$ & & Turkey \\
\hline $\begin{array}{l}\text { Reform employment protection } \\
\text { legislation }\end{array}$ & Sweden & $\begin{array}{l}\text { France, Greece, New Zealand, } \\
\text { Portugal }\end{array}$ \\
\hline \multicolumn{3}{|l|}{ Taxation } \\
\hline $\begin{array}{l}\text { Simplification, reduction of distortions } \\
\text { and base broadening }\end{array}$ & Canada, Japan & Mexico, United States \\
\hline Lower labour taxes & $\begin{array}{l}\text { Belgium, Denmark, Germany, } \\
\text { Sweden }\end{array}$ & $\begin{array}{l}\text { Australia, Czech Republic, } \\
\text { Hungary, Italy, Poland, Turkey }\end{array}$ \\
\hline $\begin{array}{l}\text { Reduce implicit tax on continuing to } \\
\text { work and work at older age }\end{array}$ & $\begin{array}{l}\text { Belgium, Denmark*, Finland, } \\
\text { Germany*, Norway* }\end{array}$ & France, Greece, Spain, Turkey \\
\hline $\begin{array}{l}\text { Reduce implicit tax on returning to } \\
\text { work following childbirth }\end{array}$ & $\begin{array}{l}\text { Austria, Germany, Korea, } \\
\text { Netherlands, Switzerland }\end{array}$ & $\begin{array}{l}\text { Ireland, New Zealand, United } \\
\text { Kingdom }\end{array}$ \\
\hline Financial regulation & & \\
\hline $\begin{array}{l}\text { Privatisation, non-performing loans, } \\
\text { regulation and supervision }\end{array}$ & Japan, Korea & United States \\
\hline
\end{tabular}

(1) Refers to the assessment of progress made in implementing Going for Growth recommendations (OECD, 2010b). The list refers to countries where actions have been taken to address the relevant policy priority identified in previous reviews. Countries where actions have been taken and resulted in the removal of the policy priority in subsequent reviews are identified with an asterisk.

(2) Based on the average current account balances during 2005-09.

Source: Going for Growth database. 
It does not, however, consider the composition of reform packages and the effect of different initiatives on savings and unemployment in different countries. But review of policy implementation to address the priorities identified in the OECD's regular surveillance of structural reform in the Organisation's member countries and in an increasing number of large emerging-market economies outside the OECD membership suggests that steps have been taken in areas that would have a bearing on their current account positions (Table A2.1). ${ }^{2}$ In most cases, initiatives have focused on product market regulations, financial sector reform (with emphasis on regulation) and tax reform (with emphasis on an alleviation of the tax burden on labour income). ${ }^{3}$

\section{Product Market Regulations}

- Product market deregulation that removes barriers to entry may foster foreign investment (Alesina et al., 2005), which may weaken the current account balance before balancing mechanisms gradually set in (Kennedy and Sløk, 2005). However, to the extent that these reforms also affect labour productivity and trade competitiveness, it is possible that the current account surplus may rise once the effects of deregulation on investment subside. It is therefore particularly difficult to ascertain the net effect of product market reforms on the external positions of surplus and deficit countries.

- Surveillance of structural policies in OECD member countries and major emerging-market economies outside the OECD area shows that action has been taken in several countries to make product market regulations more pro-competition. In the case of Germany, for example, effort has been made to reduce barriers to professional services. Further reform to this effect would be desirable, because the non-tradable sector, particularly services, remains shielded from productivity-enhancing competition that could unleash opportunities for investment and therefore contribute to a reduction in the country's large current account surplus (OECD, 2010b and 2010c).

- Notwithstanding progress in many areas in recent years, further product market reforms remain a priority in deficit and surplus countries alike. This includes a strengthening of competition in

\footnotetext{
${ }^{2}$ The OECD carries out a regular surveillance of structural policies in the Organisation's member countries with emphasis on those policy actions that are associated with better outcomes in terms of potential output. The exercise is instructive from the viewpoint of assessing the effect of structural reform on global imbalances, because several pro-growth initiatives also have a sideeffect of affecting a country's current account position through their impact on saving and investment behaviour.

${ }^{3}$ See de Mello and Padoan (2010) for more information and discussion on the basis of empirical analysis carried out at the OECD.
} 
network industries (Australia, the European Union at large, Mexico) and professional services (Canada), an alleviation of regulatory barriers to competition (Brazil, France and Germany), and a reduction of public ownership (Italy, India, Indonesia) and restrictions on foreign investment (Indonesia, Japan, Mexico).

\section{Financial Market Regulation}

- Empirical evidence for OECD countries shows that financial reform is associated with a weakening of the current account balance in the short term (Cheung et al., 2010; Kennedy and Sløk, 2005). This is essentially because of the scope for financial market reforms to unleash opportunity for investment (e.g. Cheung et al., 2010; OECD, 2003; Pelgrin et al., 2002), which may attract capital inflows. Action taken to strengthen financial markets in surplus countries, such as Japan and Korea, may therefore contribute to reducing their current account surpluses. In Korea, for example, there has been considerable progress in the privatisation of banks and investment trust companies to extent pro-competition reforms to banking and financial sector at large.

- At the same time, reform to deepen financial markets in emergingmarket surplus countries would allow for excess savings to be invested domestically, which would be associated, all else equal, with a reduction in these countries' current account surpluses. Such policies would have the side effect of reducing demand for the financial assets of deficit countries with deeper, more liquid financial markets and would therefore contribute to lowering external imbalances on a global scale. However, financial liberation has been slow in China, despite progress in opening up the financial sector to international investors and in allowing domestic investors to invest abroad (Herd et al., 2010).

\section{Employment Protection Legislation}

- Efforts to raise effective labour supply by removing regulatory impediments in labour market regulations would affect the current account by boosting trade competitiveness (if domestic demand for labour is not fully elastic) and the profitability of domestic capital (Kennedy and Sløk, 2005). Deficit countries would benefit from structural reforms to enhance wage flexibility and reduce the non-

\footnotetext{
${ }^{4}$ It has been argued that, due to a savings glut in East Asia, demand for foreign financial assets by these countries has been the main driver of the current-account deficit in the United States (Bernanke, 2005; Caballero et al., 2008; Obstfeld and Rogoff, 2009).
} 
wage components of labour compensation, which could help to improve competitiveness by damping the growth of unit labour costs.

- There has been relatively limited progress in reforming employment protection legislation in most countries since 2005, although action has been taken to reform disability and sickness benefits in Australia and United Kingdom. Turkey has taken steps to cut social security contributions for low-wage earners. Brazil has also taken action to alleviate the tax burden on labour income (OECD, 2009c). A reform of minimum wage setting has been recommended for Indonesia (OECD, 2008) as a means of reducing barriers to the formalisation of labour relations, but action has yet to be taken.

\section{Social Safety Nets}

- Specific social reforms may influence savings decisions and subsequently the current account balance. The responsiveness of household savings to increases in government-financed social spending also tends to be stronger in countries with low levels of social spending (Baldacci et al., 2010; Furceri and Mourougane, 2010). ${ }^{5}$ Otherwise desirable policy initiatives, such as a strengthening of formal social safety nets, which would reduce public savings through an increase in social spending, could also have the side-effect of reducing household savings in some surplus emerging-market economies. Empirical evidence for China suggests that pension and health care reforms have a significant impact on household saving. ${ }^{6}$

\section{Tax Policy}

- Tax reforms affect the investment and saving decisions of firms and households through their impact on after-tax income, the after-tax rate of return on saving and the tax deductibility of the expenses for fixed assets (depreciation allowances) and of interest expenses on loans. Corporate tax cuts and increases in depreciation allowances boost firm investment (Vartia, 2008; Schwellnus and Arnold, 2008). Tax reform could reduce incentives for over-consumption in deficit countries, such as the United States. This could be achieved, for example, by

\footnotetext{
${ }^{5}$ The results imply, for example, that a $1 \%$ increase in social spending would reduce the saving-toGDP ratio by about $1 / 2$ percentage point in the average OECD country, but by as much as 1 percentage point in China. Barnett and Brooks (2010) show that an increase in health spending by one renminbi leads to up to a two renminbi increase in urban household consumption. As a result the projected increase by $13 / 4$ percentage points of GDP in social spending in China could reduce saving by about $1 \frac{1 / 2-2 \%}{2}$ of GDP in the medium and long terms.

${ }^{6}$ Feng et al. (2009) show that the pension reform for enterprise employees in China implemented in the late 1990s lowered pension wealth and raised household savings. See also OECD (2010d) for more information.
} 
scrapping income tax deductibility for mortgage payments or shifting the personal income tax further to a consumption base, would have an influence on the current account. It should nevertheless be recognised that empirical evidence on the effect of tax reform on the current account balanced is fairly mixed. Reducing the average tax wedge would improve the current account balance through an increase in exports and a decrease in imports (Nicoletti et al., 2003), an increase in investment (OECD, 2003; Alesina et al., 2002) and a decrease in net FDI outflows (Nicoletti et al., 2003). On the other hand, a reduction in the overall tax burden would weaken the current account balance (Kennedy and Sløk, 2005).

\section{Other Policy Areas}

- Other structural reforms may have an effect on the current account. Initiatives to reduce oil consumption could lower the current account deficit in oil-importing countries, although the final impact depends on how such policies affect the fiscal deficit and consumption of other goods. 